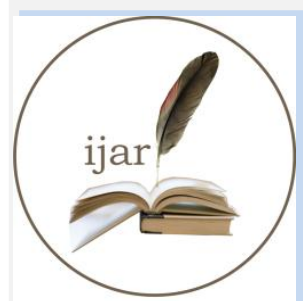

ISSN NO. 2320-5407

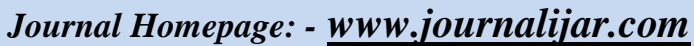 \\ INTERNATIONAL JOURNAL OF ADVANCED RESEARCH (IJAR)}

Article DOI: $10.21474 /$ IJAR01/10267

DOI URL: http://dx.doi.org/10.21474/IJAR01/10267
INTERNATIONAL JOURNAL OF ADVANCED RESEARCH (IJAR)

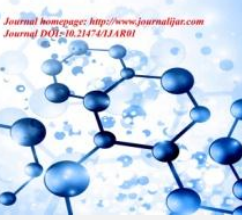

RESEARCH ARTICLE

\title{
PREVALENCE OF HEMORRHOIDS AND ASSOCIATED COMPLICATIONS IN KINGDOM OF SAUDI ARABIA
}

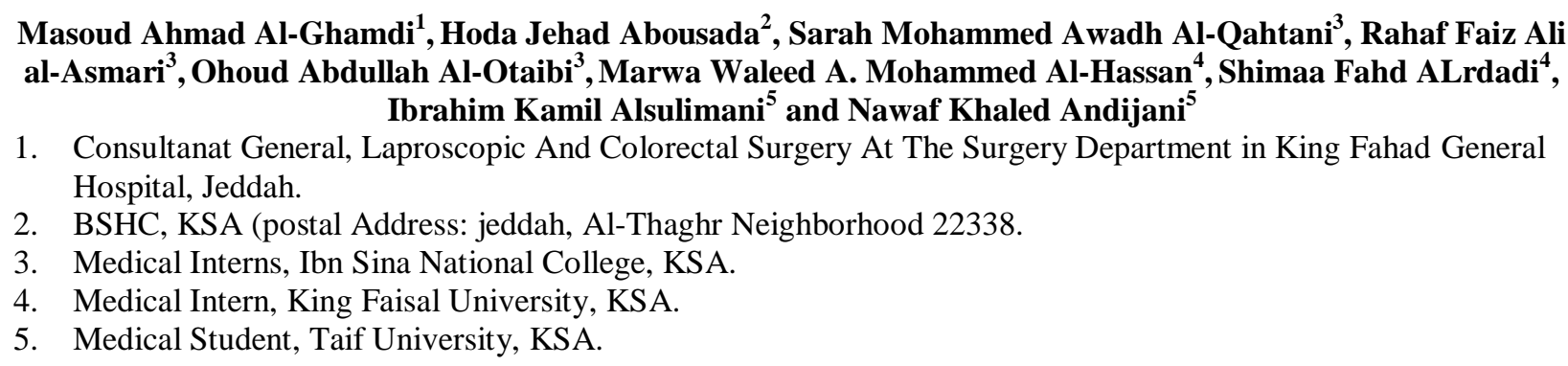

\section{Manuscript Info}

Manuscript History

Received: 15 November 2019

Final Accepted: 22 December 2019

Published: January 2020

\section{Abstract}

\section{Introduction:-}

Hemorrhoids are swollen veins located around the anus or in the lower rectum. About 50 percent of adults experienced the symptoms of hemorrhoids by the age of 50. Hemorrhoids can either be internal or external. Internal hemorrhoids develop within the anus or rectum.

\section{Rationale:}

This research will add new findings on the prevalence of hemorrhoids in the general population to this time and the associated complications. Also, it is important to know the extent of intellectual awareness of this subject, as shyness from a clinical medical examination may increase the incidence of complications.

\section{Research question:}

Questionnaire.

Aim :

To determine the prevalence of hemorrhoid and associated complications.

\section{Objective:-}

The main objective:

To determine the prevalence of hemorrhoid and associated complications

The sub- objectives:

1- To identify the most gender affected.

2- To identify the most affected type of hemorrhoids. 
3- To identify the most symptoms associated with hemorrhoids.

4- To see how much the general public expresses intellectual awareness about the:

a) Most common cause of hemorrhoids.

b) Do not go to the doctor because of feeling ashamed.

Method and Design:-

Study design:

Cross sectional study.

Study area:

Kingdom of Saudi Arabia

\section{Study setting:}

The study will be carried out by questionnaire.

Study population:

Inclusion criteria:

Adult general population

Exclusion criteria:

non

\section{Data Collection Methods:-}

Data collection tool:

Self-administered questionnaire partially constructed by the researcher with reference to already made questionnaire in another study .Validity will be checked by at consultant.

Data collection technique:

The researcher will distribute the questionnaire.

Study sample and technique:

Questionnaire from the general adult population

\section{Sample size:}

1172

Sample technique:

Questionnaire.

\section{Data entry and statistical analysis:}

The data will be entered into a personal computer and it will be analyzed using Statistical Package for the Social Sciences (SPSS).

\section{Results:-}

Questionnaire of the prevalence of hemorrhoids and associated complications in an adult general population.

1172 responses were collected showing the following results and conclusion : 


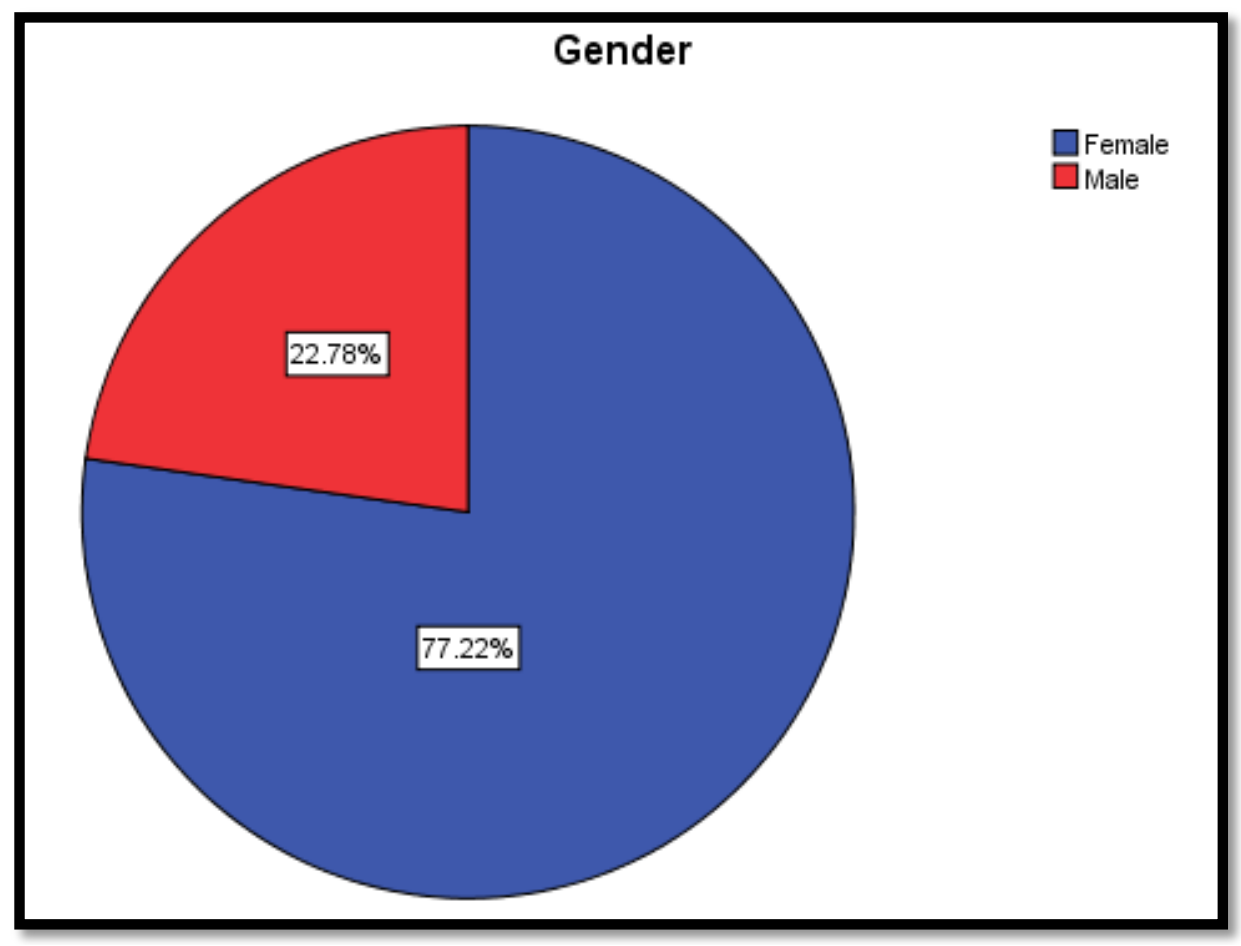

The results indicate that most respondents are females.

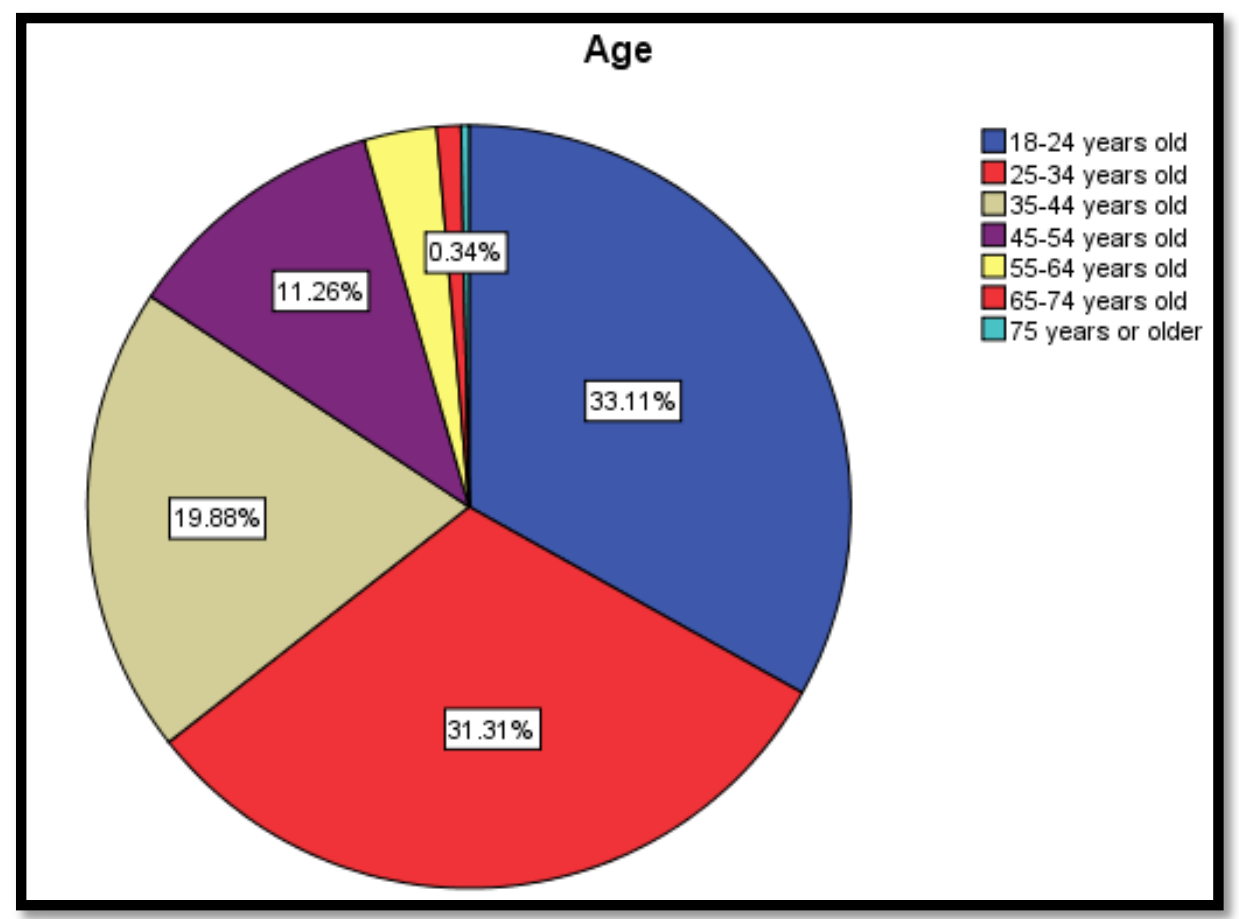

The results show that most of the respondents are between 18-34 years old. 


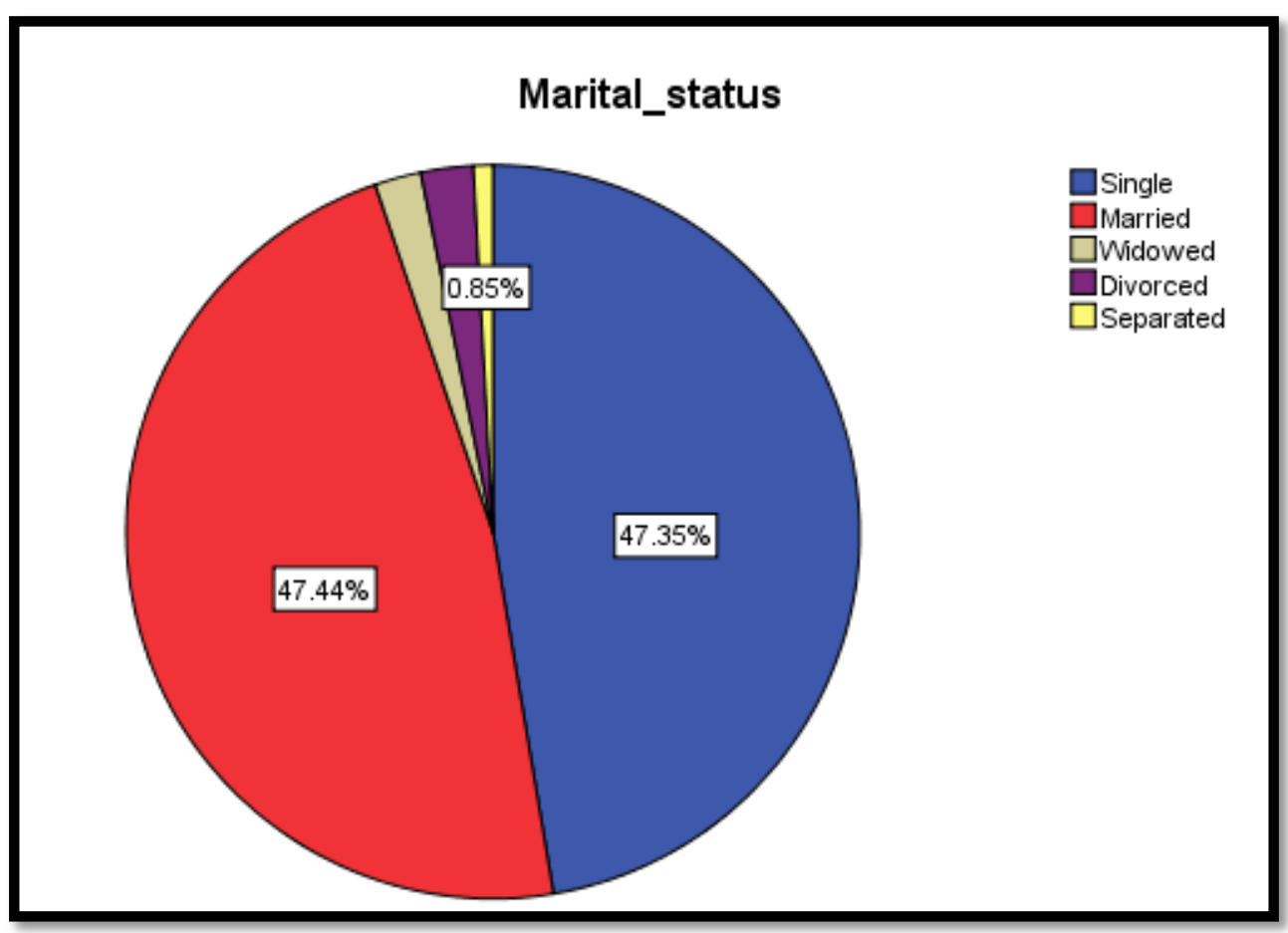

The results showed that the majority of the marital status of the respondents are either married or single in equal proportions.

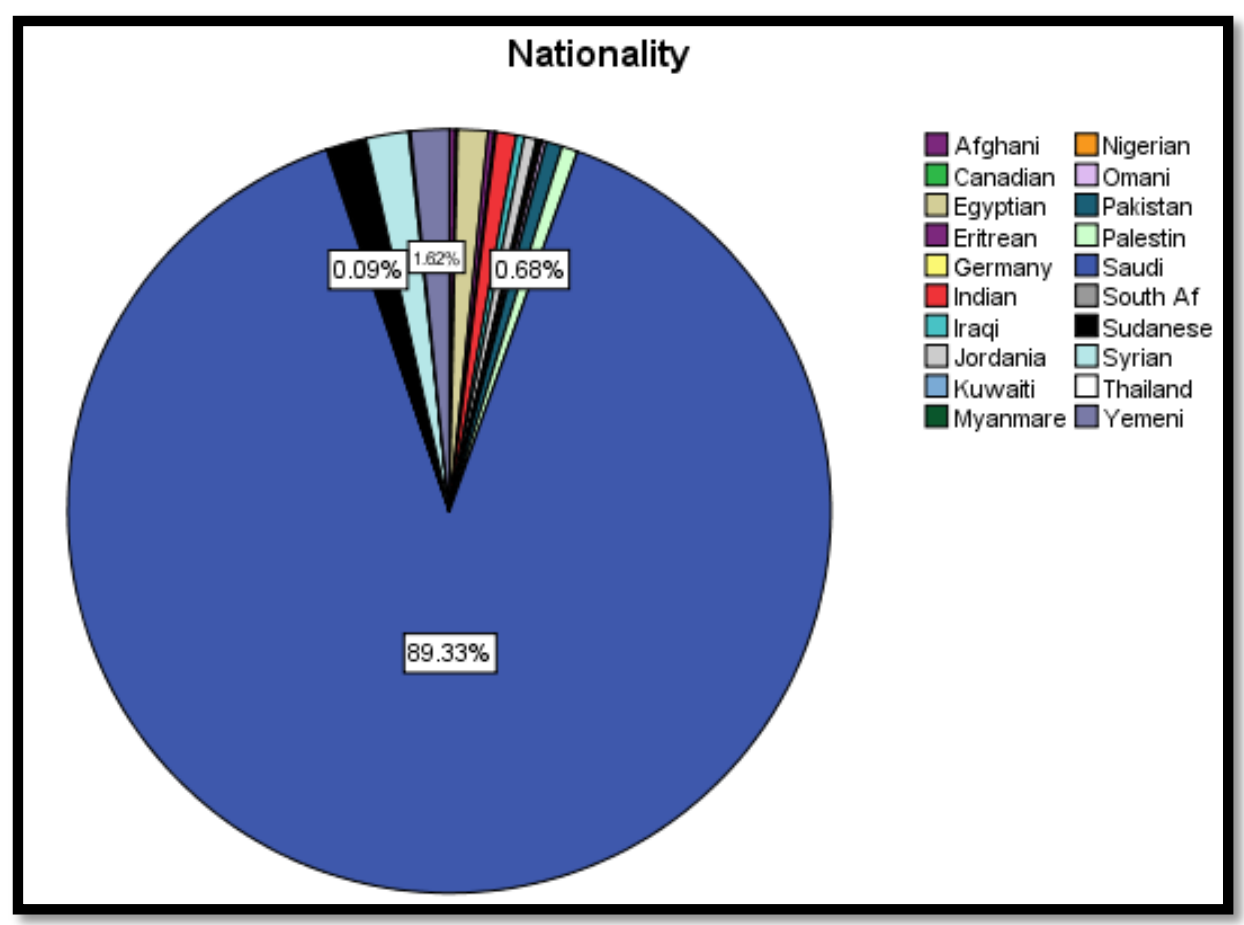

The results show that most of the respondents are Saudis. 


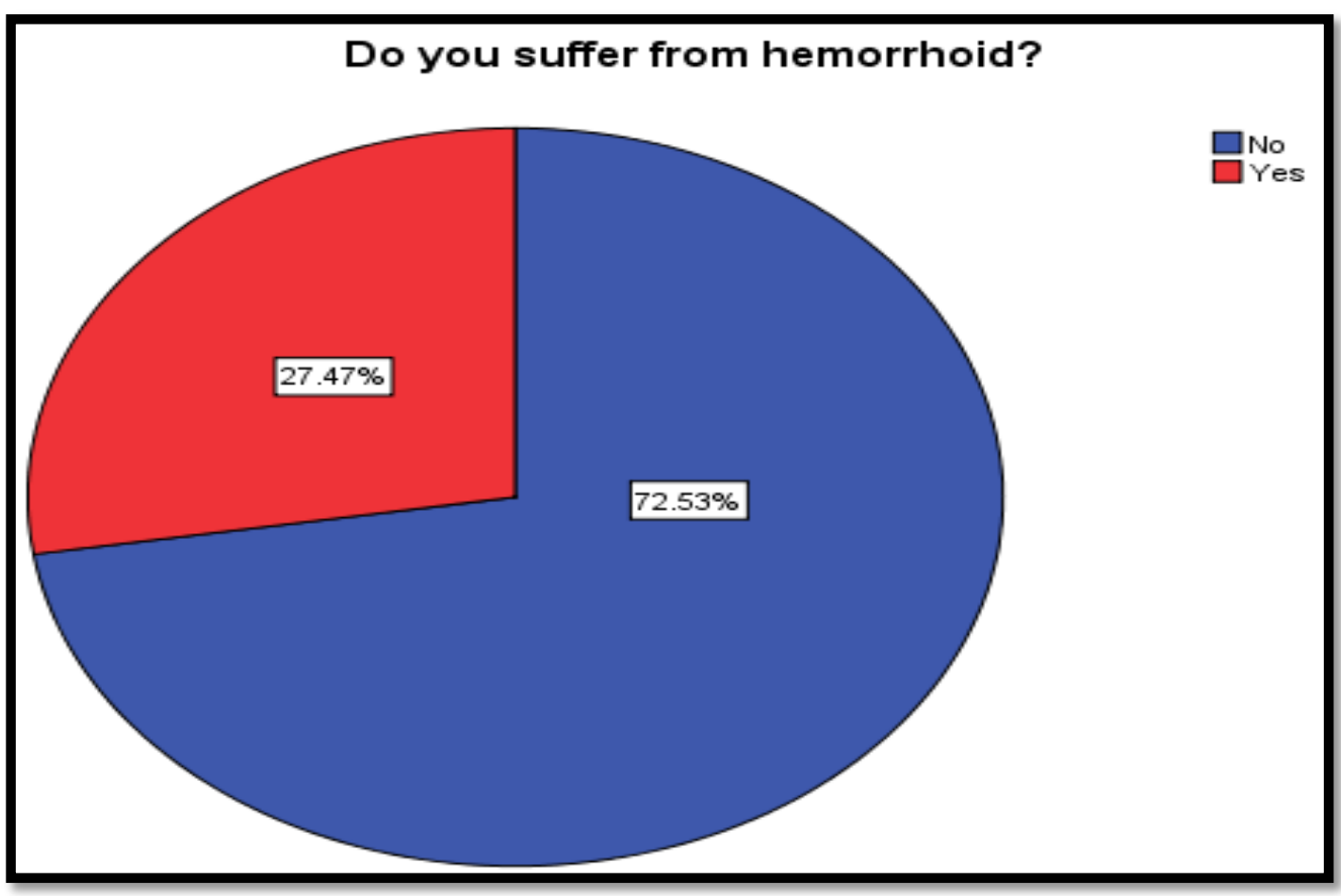

The results showed that $27 \%$ of the respondents had hemorrhoids.

\begin{tabular}{|c|c|c|c|c|c|}
\hline \multicolumn{6}{|c|}{ What type of hemorrhoids infected? } \\
\hline & & Frequency & Percent & Valid Percent & $\begin{array}{c}\text { Cumulative } \\
\text { Percent }\end{array}$ \\
\hline \multirow[t]{4}{*}{ Valid } & Internal hemorrhoid & 112 & 9.6 & 31.9 & 31.9 \\
\hline & External hemorrhoid & 223 & 19.0 & 63.5 & 95.4 \\
\hline & Thrombosed hemorrhoid & 16 & 1.4 & 4.6 & 100.0 \\
\hline & Total & 351 & 29.9 & 100.0 & \\
\hline
\end{tabular}

The results showed most of the respondents who have hemorrhoids they suffer from external hemorrhoid.

\begin{tabular}{|c|c|c|c|c|c|}
\hline \multicolumn{6}{|c|}{ Do you feel pain? } \\
\hline & & Frequency & Percent & Valid Percent & $\begin{array}{c}\text { Cumulative } \\
\text { Percent }\end{array}$ \\
\hline \multirow[t]{3}{*}{ Valid } & No & 143 & 12.2 & 37.0 & 37.0 \\
\hline & Yes & 244 & 20.8 & 63.0 & 100.0 \\
\hline & Total & 387 & 33.0 & 100.0 & \\
\hline
\end{tabular}

The results showed most of the respondents who have hemorrhoids feel pain. 


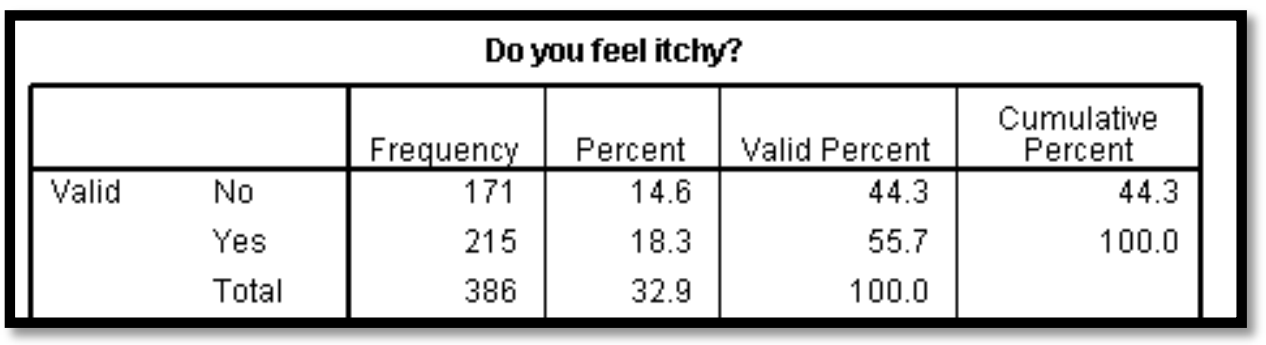

The results showed most of the respondents who have hemorrhoids feel itchy.

\begin{tabular}{|c|c|c|c|c|c|}
\hline \multicolumn{6}{|c|}{ Do you feel burning sensation during micturition? } \\
\hline & & Frequency & Percent & Valid Percent & $\begin{array}{c}\text { Cumulative } \\
\text { Percent }\end{array}$ \\
\hline \multirow[t]{3}{*}{ Valid } & No & 269 & 23.0 & 70.1 & 70.1 \\
\hline & Yes & 115 & 9.8 & 29.9 & 100.0 \\
\hline & Total & 384 & 32.8 & 100.0 & \\
\hline
\end{tabular}

The results showed most of the respondents who have hemorrhoids do not feel burning sensation during micturition.

\begin{tabular}{|c|c|c|c|c|c|}
\hline \multicolumn{6}{|c|}{ Since when you suffer from it? } \\
\hline & & Frequency & Percent & Valid Percent & $\begin{array}{c}\text { Cumulative } \\
\text { Percent }\end{array}$ \\
\hline \multirow[t]{4}{*}{ Valid } & $<6$ months & 80 & 6.8 & 22.0 & 22.0 \\
\hline & $1-2$ years & 86 & 7.3 & 23.7 & 45.7 \\
\hline & $=2$ years & 197 & 16.8 & 54.3 & 100.0 \\
\hline & Total & 363 & 31.0 & 100.0 & \\
\hline
\end{tabular}

The results showed that most of the respondents suffering from hemorrhoids had suffered from it for more than two years.

\begin{tabular}{|c|c|c|c|c|c|}
\hline \multicolumn{6}{|c|}{ Do you suffer from complications of hemorrhoids? } \\
\hline & & Frequency & Percent & Valid Percent & $\begin{array}{c}\text { Cumulative } \\
\text { Percent }\end{array}$ \\
\hline \multirow[t]{4}{*}{ Valid } & No & 168 & 14.3 & 44.0 & 44.0 \\
\hline & Yes & 88 & 7.5 & 23.0 & 67.0 \\
\hline & I dont know & 126 & 10.8 & 33.0 & 100.0 \\
\hline & Total & 382 & 32.6 & 100.0 & \\
\hline
\end{tabular}

The results showed that most of the respondents suffering from hemorrhoids do not suffer from complications of hemorrhoids. 


\begin{tabular}{|c|c|c|c|c|c|}
\hline \multicolumn{6}{|c|}{ Determine the complications you are experiencing? } \\
\hline & & Frequency & Percent & Valid Percent & $\begin{array}{c}\text { Cumulative } \\
\text { Percent }\end{array}$ \\
\hline \multirow[t]{7}{*}{ Valid } & Nothing لآتئ & 208 & 17.7 & 59.8 & 59.8 \\
\hline & sever hemorrhage & 43 & 3.7 & 12.4 & 72.1 \\
\hline & Anemia & 21 & 1.8 & 6.0 & 78.2 \\
\hline & strangulated hemorrhoid & 28 & 2.4 & 8.0 & 86.2 \\
\hline & Ulceration & 41 & 3.5 & 11.8 & 98.0 \\
\hline & Fibrosis تُبِف Fib & 7 & .6 & 2.0 & 100.0 \\
\hline & Total & 348 & 29.7 & 100.0 & \\
\hline
\end{tabular}

The results showed that the most common type of complication in patients with hemorrhoids is ulceration and sever hemorrhage.

\begin{tabular}{|c|c|c|c|c|c|}
\hline \multicolumn{6}{|c|}{ What is your treatment plan? } \\
\hline & & Frequency & Percent & Valid Percent & $\begin{array}{c}\text { Cumulative } \\
\text { Percent }\end{array}$ \\
\hline \multirow[t]{4}{*}{ Valid } & I didn't treat that & 197 & 16.8 & 52.5 & 52.5 \\
\hline & By medication & 120 & 10.2 & 32.0 & 84.5 \\
\hline & By surgery & 58 & 4.9 & 15.5 & 100.0 \\
\hline & Total & 375 & 32.0 & 100.0 & \\
\hline
\end{tabular}

The results showed that most of the respondents were not treated and those who were treated were treated with medication.

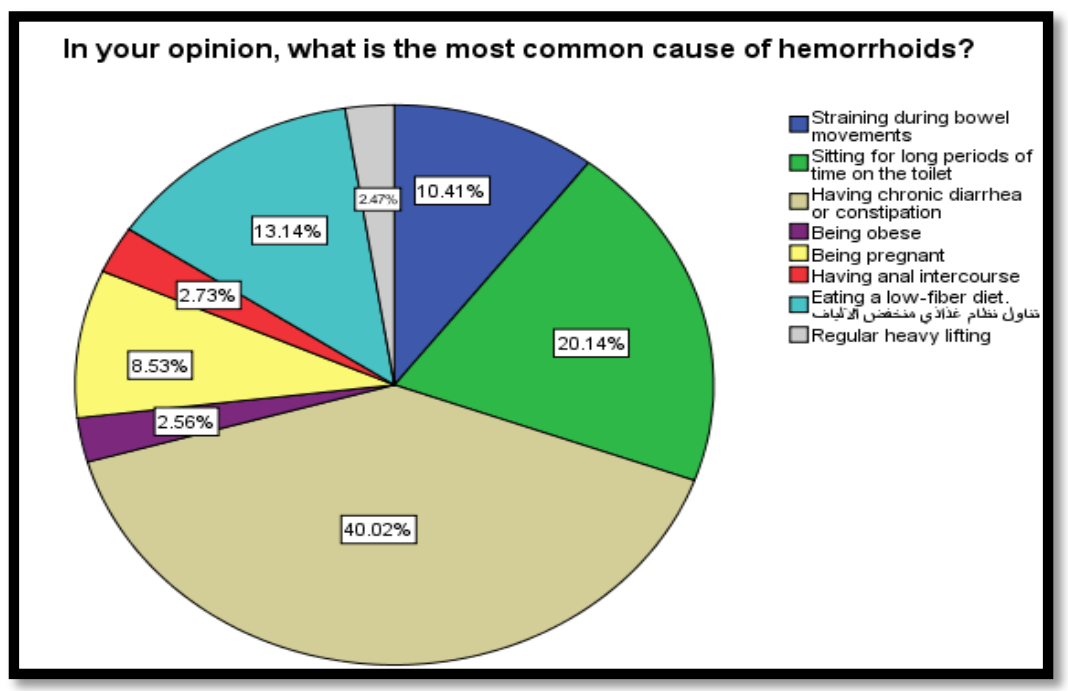

The results showed that most of the respondents believed that the most important reason behind hemorrhoids is chronic diarrhea or constipation. 


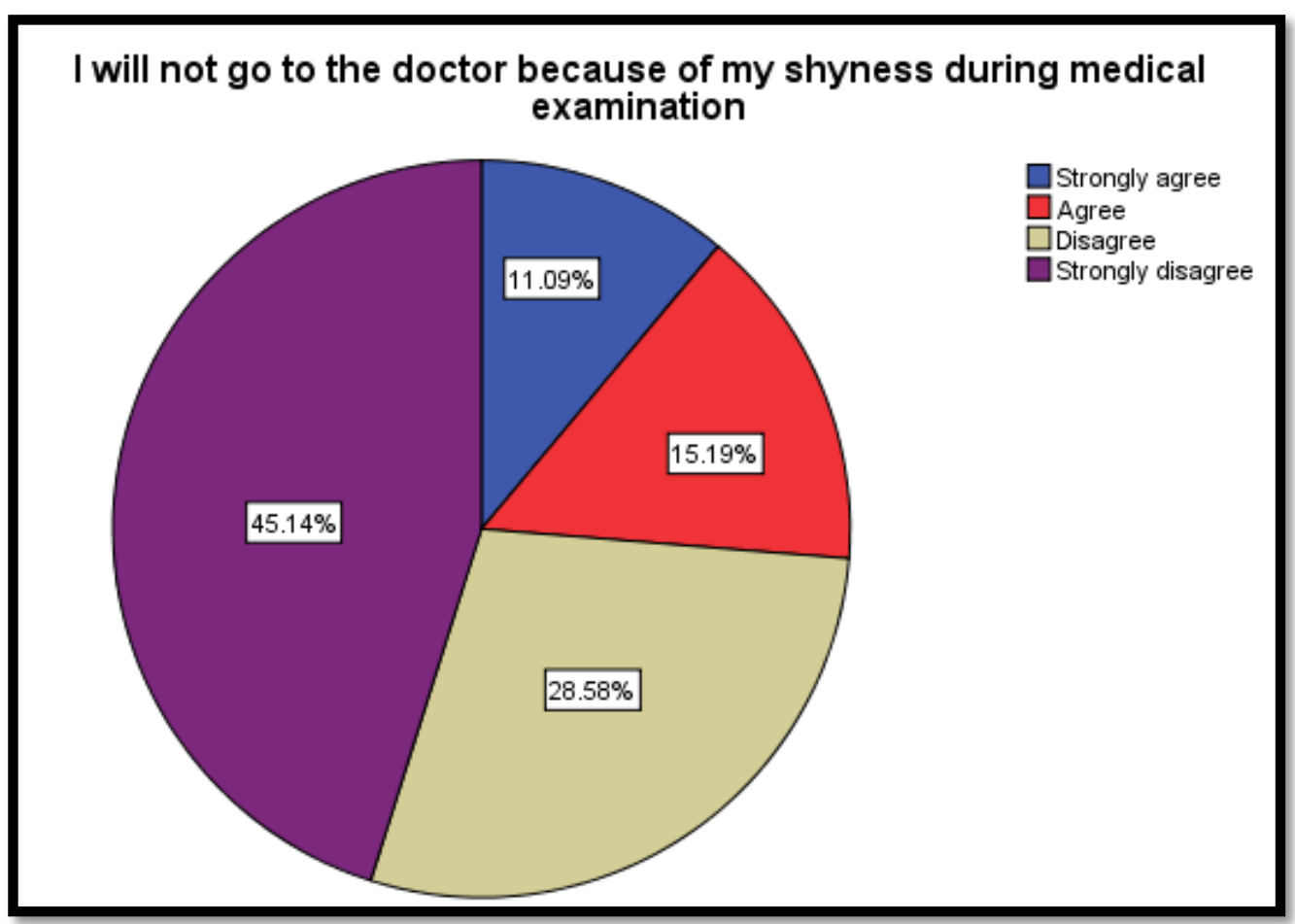

The results showed that the majority of respondents did not find any embarrassment in going to the doctor for examination.

\section{Correlations:}

\begin{tabular}{|c|c|c|c|}
\hline \multicolumn{4}{|c|}{ Correlations } \\
\hline & & $\begin{array}{l}\text { What is your } \\
\text { treatment } \\
\text { plan? }\end{array}$ & $\begin{array}{l}\text { Do you feel } \\
\text { burning } \\
\text { sensation } \\
\text { during } \\
\text { micturition? }\end{array}$ \\
\hline $\begin{array}{l}\text { What is your treatment } \\
\text { plan? }\end{array}$ & $\begin{array}{l}\text { Pearson Correlation } \\
\text { Sig. (2-tailed) } \\
N\end{array}$ & $\begin{array}{r}1 \\
375\end{array}$ & $\begin{array}{r}.122^{x} \\
.019 \\
369\end{array}$ \\
\hline $\begin{array}{l}\text { Do you feel burning } \\
\text { sensation during } \\
\text { micturition? }\end{array}$ & $\begin{array}{l}\text { Pearson Correlation } \\
\text { Sig. (2-tailed) } \\
N\end{array}$ & $\begin{array}{r}.122^{\pi} \\
.019 \\
369\end{array}$ & $\begin{array}{r}1 \\
384\end{array}$ \\
\hline
\end{tabular}

${ }^{*}$. Correlation is significant at the 0.05 level (2-tailed).

$\mathrm{P}$ value is 0.019 which means there is a strong relationship between the treatment plan and feeling burning sensation during micturition. 


\begin{tabular}{|ll|r|r|}
\hline \multicolumn{3}{|c|}{ Correlations } \\
\hline & $\begin{array}{c}\text { Do you feel } \\
\text { pain? }\end{array}$ & $\begin{array}{c}\text { Doyou feel } \\
\text { itchy? }\end{array}$ \\
\hline Do you feel pain? & Pearson Correlation & 1 & $.351^{\text {xx }}$ \\
& Sig. (2-tailed) & & .000 \\
& $\mathrm{~N}$ & 387 & 381 \\
\hline Do you feel itchy? & Pearson Correlation & $.351^{\times x}$ & 1 \\
& Sig. (2-tailed) & .000 & 386 \\
& $\mathrm{~N}$ & 381 & \\
\hline
\end{tabular}

\#. Correlation is significant at the 0.01 level (2-tailed).

$\mathrm{P}$ value is 0.000 which means there is a strong relationship between feeling pain and itchy.

\begin{tabular}{|c|c|c|c|}
\hline \multicolumn{4}{|c|}{ Correlations } \\
\hline & & $\begin{array}{l}\text { Do you feel } \\
\text { pain? }\end{array}$ & $\begin{array}{l}\text { Do you suffer } \\
\text { from } \\
\text { hemorrhoid? }\end{array}$ \\
\hline \multirow[t]{3}{*}{ Do you feel pain? } & Pearson Correlation & 1 & $.260^{\mathrm{xx}}$ \\
\hline & Sig. (2-tailed) & & .000 \\
\hline & $\mathrm{N}$ & 387 & 387 \\
\hline \multirow{3}{*}{$\begin{array}{l}\text { Do you suffer from } \\
\text { hemorrhoid? }\end{array}$} & Pearson Correlation & $.260^{x \pi}$ & 1 \\
\hline & Sig. (2-tailed) & .000 & \\
\hline & $N$ & 387 & 1172 \\
\hline
\end{tabular}

$\mathrm{P}$ value is 0.000 which means there is a strong relationship between feeling pain and suffering from hemorrhoid.

\begin{tabular}{|c|c|c|c|}
\hline \multicolumn{4}{|c|}{ Correlations } \\
\hline & & $\begin{array}{c}\text { Do you suffer } \\
\text { from } \\
\text { complications } \\
\text { of } \\
\text { hemorrhoids? }\end{array}$ & $\begin{array}{c}\text { Do you feel } \\
\text { pain? }\end{array}$ \\
\hline \multirow{3}{*}{$\begin{array}{l}\text { Do you suffer from } \\
\text { complications of } \\
\text { hemorrhoids? }\end{array}$} & Pearson Correlation & 1 & $.194^{\pi x}$ \\
\hline & Sig. (2-tailed) & & .000 \\
\hline & $N$ & 382 & 378 \\
\hline \multirow[t]{3}{*}{ Do you feel pain? } & Pearson Correlation & $.194^{\pi x}$ & 1 \\
\hline & Sig. (2-tailed) & .000 & \\
\hline & $\mathbb{N}$ & 378 & 387 \\
\hline
\end{tabular}

$\mathrm{P}$ value is 0.000 which means there is a strong relationship between feeling pain and suffering from complications of hemorrhoid. 


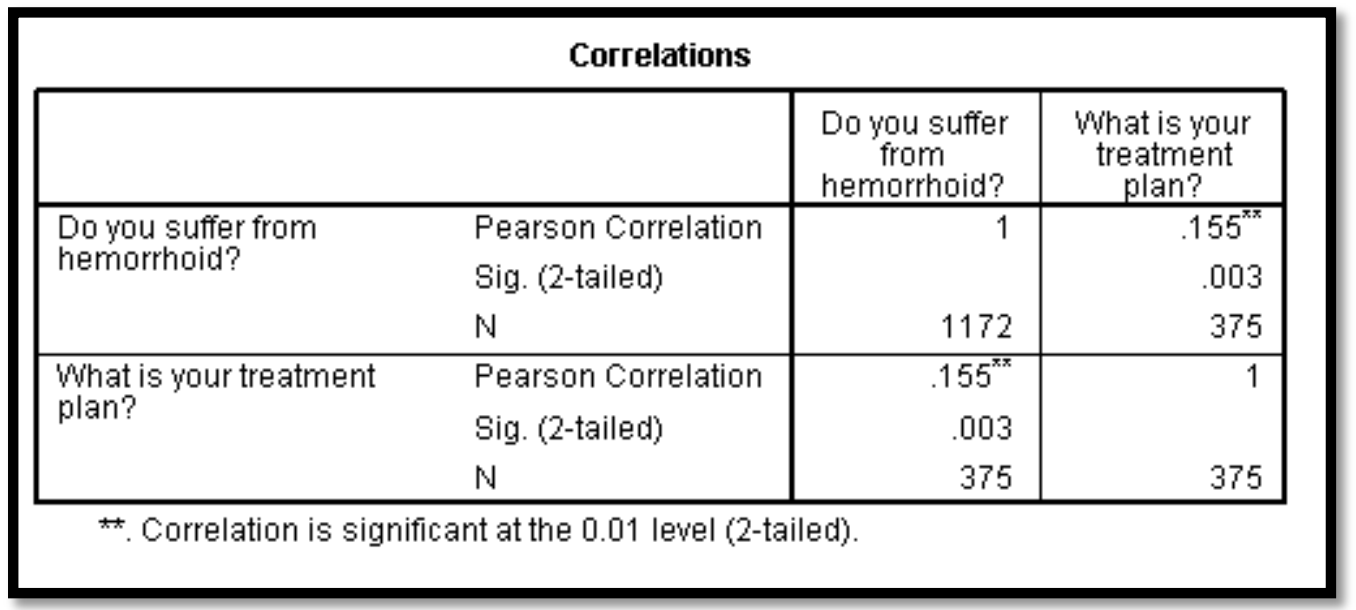

$\mathrm{P}$ value is 0.003 which means there is a strong relationship between suffering from hemorrhoid and the treatment plan.

\begin{tabular}{|ll|r|r|}
\hline \multicolumn{4}{|c|}{ Correlations } \\
\hline \multicolumn{1}{|c|}{} & $\begin{array}{c}\text { What is your } \\
\text { treatment } \\
\text { plan? }\end{array}$ & \multicolumn{1}{c|}{ Age } \\
\hline $\begin{array}{l}\text { What is your treatment } \\
\text { plan? }\end{array}$ & Pearson Correlation & 1 & $.263^{\mathrm{x}}$ \\
& Sig. (2-tailed) & & .000 \\
& $\mathrm{~N}$ & 375 & 375 \\
\hline Age & Pearson Correlation & $.263^{\mathrm{xx}}$ & 1 \\
& Sig. (2-tailed) & .000 & 1172 \\
\hline
\end{tabular}

$\#$ Correlation is significant at the 0.01 level (2-tailed).

$\mathrm{P}$ value is 0.000 which means there is a strong relationship between receiving the treatment plan and the age.

\section{Discussion:-}

This study was based on a number of 1172 participants, from this study as the number of females is 905 and males is 267 and , 322 of them suffer from hemorrhoids which is considering as unhealthy sign requires going to the doctor for a health check-up,.

The current study showed statistically significant ( $\mathrm{P}$ value is 0.000 ) which means which means there is a strong relationship between feeling pain and itchy, ( $\mathrm{P}$ value is 0.019$)$ which means there is a strong relationship between the treatment plan and feeling burning sensation during micturition.

( $\mathrm{P}$ value is 0.000 ) which means there is a strong relationship between feeling pain and suffering from hemorrhoid.

\section{Conclusion:-}

The results showed very positive results due to the low percentage of people with hemorrhoids. People with hemorrhoids experience many symptoms, including itching and pain.

Hemorrhoids cause many complications, including severe bleeding and ulceration. Most people with hemorrhoids have been treated with medication. 
$40 \%$ of the respondents think that the most important cause of hemorrhoids is having chronic diarrhea or constipation.

\section{Recommendation:-}

We recommend setting up health education programs about the hemorrhoids, This health problem must be presented broadly and beneficially and, in a way, that everyone understands, as most deal with the hemorrhoids by ignoring and not being important, work should be done on health conferences and medical discussions on that.

\section{Acknowledgement:-}

The authors would like to thank the participants We thank the data collectors: Dr. Taghreed Faisal Alawi for her great cooperation, Participants will be carried out by questionnaire.

\section{Ethical consideration:}

- Individual consent from participants ( written on the front page of the questionnaire).

-All information will be kept confidential.

\section{Budget:}

Self funded

This research did not receive any specific grant from funding agencies in the public, commercial, or not-for-profit sectors.

\section{Appendices: \\ ( Questionnaire )}

Questionnaire of the prevalence of hemorrhoids and associated complications in an adult general population.

1- Gender: الجنس

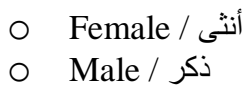

2- Age: العمر
○ 18-24 years old
○ 25-34 years old
○ 35-44 years old
○ 45-54 years old
○ 55-64 years old
○ 65-74 years old
○ 75 years or older

3- Marital_status: الحالة الاجتماعية

O اعزب Single

م متزوج/ة Married

O Widowed

O مطلق/ة Divorced

O منفصل/ Separated

4- Nationality: الجنسية

5- Do you suffer from hemorrhoid? نعاني من البو اسبير

ن نعم/ Yes

O No/Y 
If your answer is (YES), go to section (2) then (3) \if your answer is (NO), go to section (3) direct.

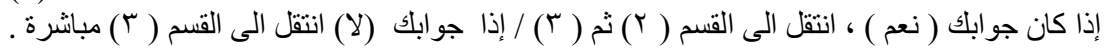

6- What type of hemorrhoids infected ? مانوع البو اسير المصاب بها ؟

O البو اسبر الداخلية Internal hemorrhoid

O البو اسير الخارجية البيرة

O Thrombosed hemorrhoid

7- Do you feel pain ? تثعر بالألم

O Yes/ نعم/

O No/Y

8- Do you feel itchy جل تشعر بالحكة ؟

O Yes/

O No/ע

9- Do you feel burning sensation during micturition? هل تثعر بحرقان اثناء التبول

O Yes/ نعم/

O No/ע

10- Since when you su!er from it? منذ متى وانت تعاني من ذلك

$0<6$ months

○ 1-2 years

$0>2$ years

11- Do you suffer from complications of hemorrhoids? هل تعاني من مضاعفات بسبب البو اسير؟

O Yes/ نعم/

O No/Y

O العلم I don't know

12- Determine the complications you are experiencing? حدد المضاعفات الني تعاني منها ؟

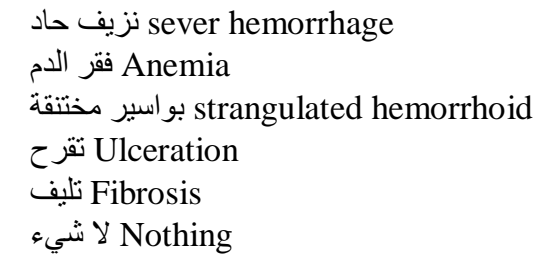

13- What is your treatment plan? ماهي خطة العلاج التي اتبعتها ؟

O من طريق الأدوية By medication

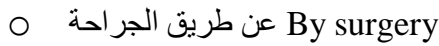

O I didn't treat that 
These are general questions, please answer them whether you are suffer from hemorrhoids or don't suffer.

هذه أسئلة عامة يرجى الإجابة عليها ما إذا كنت تعاني من البو اسير أو لا تعاني من البو اسير .

14- Since when you suffer from it? منذ منى و انت تعاني من ذلك

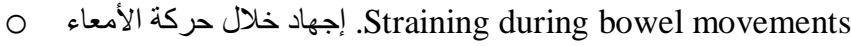

O Sitting for long periods of time on the toilet

O Having chronic diarrhea or constipation

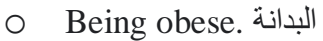

الحمل العانة

O Having anal intercourse

O Eating a low-faber diet

رفع الأثقال . Regular heavy lifting

15- I will not go to the doctor because of my shyness during medical examination انالن اذهب الى الطبيب بسبب الثعور بالخجل اثناء الفحص الطبي

O لا او افق بشدة: Strongly disagree

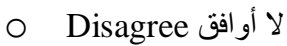

أو افق بشدة ل Strongly agree

أو افق Agree

Thank you.. 